\title{
Decision-Making Process in Japanese Board Room. Audit \& Supervisory Board as a Source of Information to Outside Board Members: A Systematic Review
}

\author{
Maria Vasileva Ilieva, Jin-ichiro Yamada \\ Osaka City University, Osaka, Japan
}

\begin{abstract}
In the context of the Corporate Governance Code enactment in Japan, we examine how newly introduced outside directors in Japanese boards obtain information to take part in the decision-making process. We conducted a systematic review of the literature and found 18 peer-reviewed publications in a time span between 2000 and 2016 that described the asymmetry of information between the insider group of board directors (including the CEO) and the outside board members. Our findings show that for the course of more than a decade, despite all changes and reforms, the role of board directors, whether insiders or outsiders, is still supplementary. They are treated more as advisors than active part in the decision-making process. We reveal different insider sources of information as forming social ties with the CEO and/or inside board directors and collaboration with Audit \& Supervisory Board (Kansayaku), which can help reduce this asymmetry and improve the decision-making process. We assume that it will be easier for the outsiders to establish contacts and form social ties with the Audit \& Supervisory Board members because of their unspoken lower status and thus to obtain more information about the company internal affairs and discussions that take place during the informal meetings, where only insiders (including the CEO) are present.
\end{abstract}

Keywords: Japanese corporate governance, decision-making role, information processing, outside board members, Audit \& Supervisory Board

\section{Introduction}

We observe the decision-making process in a particular context of Japanese corporate governance that is characterized with cooperation and collaboration between the management and Board of Directors, not so much with monitoring and control as in the Anglo-Saxon system (Dore, 2007b). Moreover, Board of Directors consists of insiders who grew up during their career up the corporate ladder (Ahmadjian, 2000) and the existence of Kansayaku or Audit \& Supervisory Board (Ahmadjian \& Okumura, 2006).

The difference between the two types of boards is in their responsibilities. While:

The Board of directors in Japanese companies are setting the broad direction of corporate strategy; establishing an environment where appropriate risk-taking by the senior management is supported; and carrying out effective oversight of directors and the management from an independent and objective standpoint. The Kansayaku board should, at minimum, ensure the establishing standards for the appropriate selection of external auditor candidates and proper evaluation of external auditors; and verify whether external auditors possess necessary independence and expertise to fulfill their responsibilities (Corporate Governance Code, 2015).

Maria Vasileva Ilieva, Ph.D. student, Graduate School of Business, Osaka City University. Email: maria.illieva@gmail.com. Jin-ichiro Yamada, Professor of Strategic Management, Graduate School of Business, Osaka City University. 
The time frame we chose is after the enactment of the Japanese Corporate Governance Code that took place in 2015. Changes towards including outside board members are about to happen in the nearest future. According to it, companies should appoint at least two independent directors who sufficiently have qualities to contribute for sustainable growth of the company and increase corporate value over the mid- to long-term. That means that they should take active part in governing and operating execution decision-making.

We use Behavior Theory on corporate governance (Westphal \& Zajac, 2013), to explain the information processing in Japanese board room. The process of reaching optimal decision needs active and effective interaction not only between the CEO and the BoD, but also between inside board members (plus the CEO) and the outside board members. The asymmetry of information between these groups can lead to difficulties for proper discussions and reaching decisions for the best outcome for the company. In the process of obtaining information, outside board members can face obstacles. Our paper examines how outside directors in Japanese boards obtain information to take part in the decision-making process.

In order to reach this goal, we first retrieved a compilation of a comprehensive data set of relevant publications. Second, we cleaned the data. Our third step was to analyze the literature and codify previous studies on Japanese corporate governance using the following criteria: author/year; type of material - article, book, book chapter; methodology; country; concepts mentioned in connection to our topic; topic. Finally, for each source, we identified the number and percentage of spread of concepts in connection to our article.

The plan of the paper is straightforward. First, we describe the decision-making process in Japanese corporate governance, differences between the two types of boards - Board of Directors and Audit \& Supervisory Board (Kansayaku), Corporate Governance Code enactment, Behavioral Theory in Japanese context and a short description of our methodology and contents of the paper. Second, we present the extant theory in the field of Japanese Board of Directors, changes of Corporate Governance Code in its part for outside directors and types of decisions, asymmetry of information and functions of Kansayaku. Third, we explain the method for gathering the sources, followed by short analysis of the results. Then, in the discussion section, we integrate previous literature on Board of Directors' decision-making, outside directors, CEO and Kansayaku. We also present our model of information processing in Japanese board rooms. Finally, we summarize the main conclusions of our study highlighting new directions for future research, and discuss the main limitations of our review.

\section{Literature Review}

In Japanese companies, Board of Directors are large and board members are often viewed as de facto managers who are subordinate to the president or CEO (Yoshikawa, Tsui-Auch, \& McGuire, 2007). By law, the Board is required to approve a wide range of decisions in the best interest of the shareholders. In reality, Boards are largely symbolic - a rubber stamp for management decisions (Ahmadjian \& Song, 2004). This is a result of the historical background, where Japanese companies have tended to grow organically, recruited employees in the very early stage of their careers, provided to them life-long careers and promoted them regularly. This leaded to obedient board members, who considered a great honor to be offered a seat on the Board, not an opportunity to give a new course to the company with the important decisions they have to take during the Board meetings. Traditionally, Japanese Boards consist of insiders. These ideas have been explored before during previous reforms - Dore (2013, p. 40): "One of the arguments of the reformers was that decision-making capacity of firms was too slow, cumbersome and inadequate to cope with what was usually referred to as ‘the intensified megacompetition’ of today’s world economy”. 
According to the last enactment of Japanese Corporate Governance Code (2015), each company should appoint at least two independent directors and effectively use their background and knowledge. One of the sub-principles of the Code states that outside board members should share information among themselves, so that they can contribute to the discussions during the Board meetings from their "independent and objective standpoint”. It is interesting to point out that one way of achieving this is with executive sessions - regular meetings consisting solely of independent directors. The meetings can also include independent Kansayaku.

Corporate Governance Code (2015) mentioned also some decisions that the Board of Directors have to take, which are connected with some major events in a company and have already been subject of interest in the extant literature: setting a strategic direction (Carpenter \& Westphal, 2001), management remuneration (Westphal \& Zajac, 1995; Ahmadjian, 2000; Geng, Yoshikawa, \& Colpan, 2016), assessment of the senior management (Walsh \& Seward, 1990; Del Brio, Yoshikawa, Connelly, \& Tan, 2013), dismissal of senior management (Walsh \& Seward, 1990; Shen \& Cannella Jr., 2002), etc. However, from practical point of view, Boards of Directors are taking more operational decisions on each and every meeting they attend: approving new products, discussing and launching new projects, company structure changes, compliance regulations; sales, income, profit ratios, etc.

In the Anglo-American type of corporate governance, the CEO or the Executive has the controlling power over information (information asymmetry). The quality of independent directors' decision-making is dependent on the quality and volume of the information flow which the CEO makes available to them (Nowak \& McCabe, 2003). In the Japanese case, the CEO and the inside board members are part of one group that have access to all the information about the company and they control what part of this information will be available for the outside board members during Board meetings. Our paper suggests that additional internal sources of information can help this asymmetry to be avoided and/or overcome.

The function of Kansayaku or Audit \& Supervisory Board has been a subject of debate in the extant literature since the early 2000s. As Ahmadjian (2000) stated in her book chapter about corporate governance and Board changes, the Kansayaku are appointed by the company to monitor the Board of Directors on behalf of shareholders and to ensure that the Board complies with the law. Also as Jackson and Moerke (2005) added, there are minimal legal distinctions between inside and outside members or between management and monitoring functions, such as the role of the statutory auditors. Moreover, Ahmadjian and Okumura (2006) claimed that Kansayaku possess limited power and no voting rights on the Board. Even if they are independent and well-qualified people, they do not have the power and resources to monitor the Chief executive and Board. Finally, in their paper for adoption of committee-based system of corporate governance, Chizema and Shinozawa (2012) explained that auditors, who may attend meetings of directors and receive regular reports from directors, tend to be internally promoted employees of the corporation, most commonly having been directors or departmental chiefs. In short, most of the sources are examining the role or functions of the Audit \& Supervisory Board but, as far as it is known to the authors, in the extant literature, there is no information for the Kansayaku board as an information provider. Therefore, we conducted a study to examine how outside directors in Japanese boards obtain information to take part in the decision-making process and how the Kansayaku board can be used as an internal source of information. 


\section{Methodology}

\section{Data Collection Process}

We undertook a review of previous studies up to 2016 on decision-making in Japanese boards and outside directors obtaining information to take part in it, in order to understand what we know and what is still missing. Following Tranfield, Denyer, and Smart (2003) framework for systematic reviews designed specifically for the management field, we made a holistic evaluation on the topic mentioned above. As a pilot search, we used "seed" papers (Janssen, Schoon, Ke, \& Börner, 2006) to allocate the other actors of interaction with Board of Directors in the present literature, except the CEO. We identified the seed papers group by choosing from literature that we were personally familiar with. We also asked for suggested literature by our academic contact list, composed by leading scholars in the area of corporate governance, especially in the Asian region and Japan in particular. We extracted keywords from the seed papers and other papers in the field, allocated by their reference list.

Regarding the main search criteria, we performed Boolean searches in the main databases (i.e., Business Source Complete; Social Sciences Citation Index (SSCI)) provided by EBSCOhost, ISI Web of Knowledge (previous Web of Science) and Google Scholar were used to search for all articles (only peer-reviewed), books and book chapters in English ${ }^{1}$ containing the terms "Decision making role" OR "information processing” AND "outside directors" in their Title/Abstract or Subject terms. We considered all journals included in the above-mentioned databases. As an area of the search, we limited it to only business and management research and for a country - Japan. Our initial search resulted in 176 publications.

We performed cleaning of the data after reading the title, abstract, keywords, research purpose or research questions of each record, if necessary, we referred to the full text of the publication. Studies were removed from the list if both reviewers agreed that a publication should not be part of the analysis. Cases of disagreement were referred back to both reviewers for re-evaluation. In the first round of cleaning, we removed papers/book chapters focused on different topics or on related topics not relevant to our study (e.g., applicable only for the US or the UK reality or focused only on stock prices dependency; or concerning particular type of industry banking or automotive), book reviews, duplicates, company reports, letters from the editors, papers published by university journals, and student papers. It resulted in 49 sources left. In the second round of cleaning, we refined the data for Japanese corporate governance and Auditing \& Supervisory Board (Kansayaku). For that reason, we removed the sources in which the studies have been conducted for other countries except Japan. This analysis enabled us to identify a final sample of 18 records (158 records were removed) that consisted of peer-reviewed articles, books and book chapters that were published in 17 sources in the years between 2000 and 2016. The cut-off was made on October 31, 2016, which includes online-first articles published up to this point.

Following previous reviews (e.g., Tranfield et al., 2003; Pugliese, Bezemer, Zattoni, Huse, Van der Bosch, \& Volberda, 2009; Cuomo, Mallin, \& Zattoni, 2016), we performed content analysis with criteria for codifying in two stages: (1) author/year; type of material - article, book, book chapter; methodology; country; concepts mentioned in connection to our topic; topic; and (2) for the concepts themselves, we identified additionally the number and percentage spread among the sources. The procedure we followed consisted of preliminary stage, in which two coders initially developed and tested the coding scheme on a sample of six articles. After that in the first phase, two different coders codified all the studies independently. Then in the second phase, we

\footnotetext{
${ }^{1}$ Some of the papers cited in this article were published in Japanese and we took them as citations from other papers published in English.
} 
matched the two sets of data in order to measure inter-rater reliability using percentage agreement (Dewey, 1983). We found a high overlap as the percentage agreement was $94 \%$ and above the appropriate minimum level of reliability. Finally, we met to discuss the few cases where there was a difference of opinion in order to reach agreement about them.

Finally, we made a descriptive analysis - short explanation of the data as numbers and percentage author/year; type of material - article/book; methodology; country; concepts mentioned; and their derivatives (Pugliese et al., 2009). And also thematic results, based on evidence per concepts mentioned: Board of Directors, outside directors, CEO, type of auditors, regulatory act, type of reform, corporate governance mechanism, process and their derivatives (e.g., Pugliese et al., 2009; Boivie, Bednar, Aguilera, \& Andrus, 2016; Khanna, Jones, \& Boivie, 2014). ${ }^{2}$

\section{Data Analyses}

Our results showed that the 18 publications evolved through time span between 2000 and 2016. In the first 5-year period, there is one publication per year with a peak in the last year (2005) with 3 publications. In the next 5-year period, there are 7 publications in 2 years only with a peak at 2007 with 6 publications. A gap in the literature follows with next publication in 2012, the trend of 1 publication per year continues till 2016 with a gap in 2014. In Figure 1, you can see the number of studies per year and their cumulative sum as a trend.

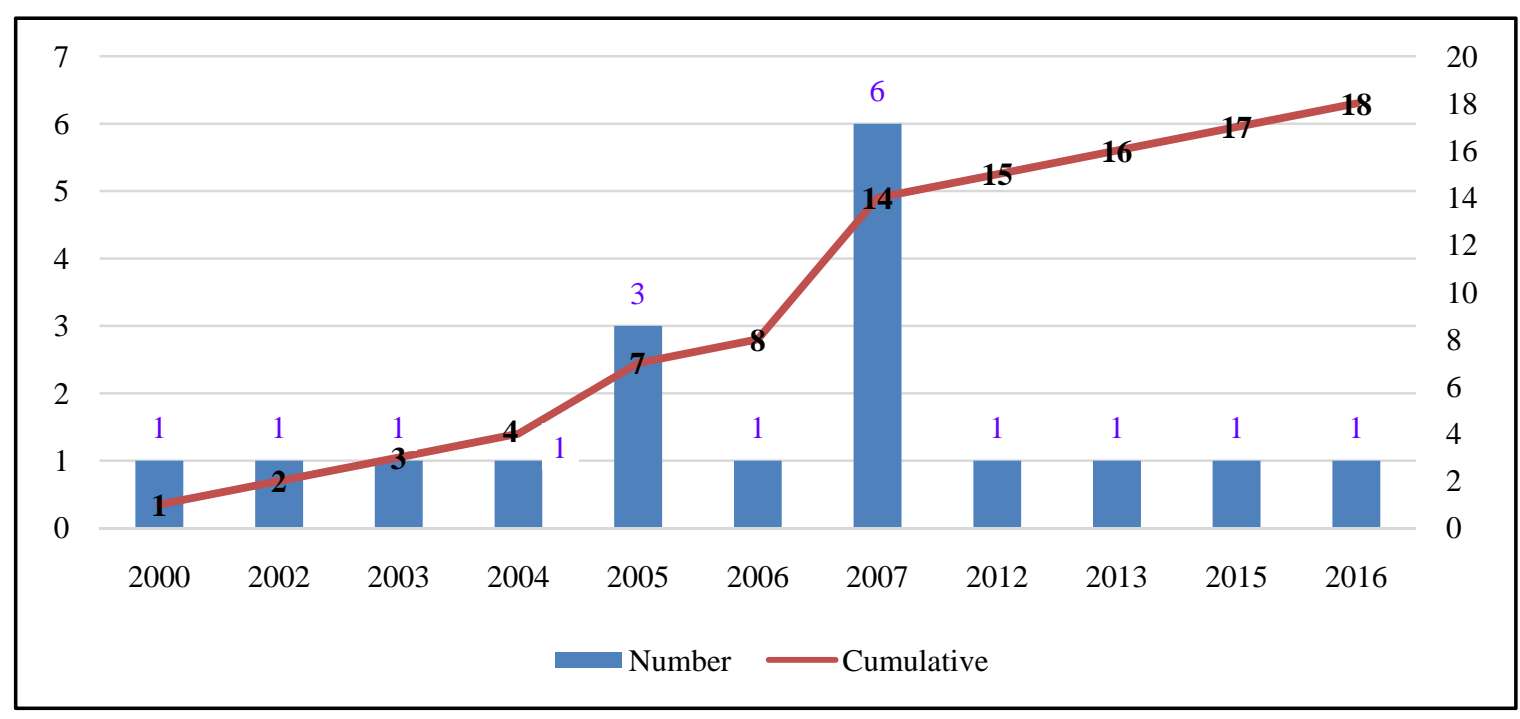

Figure 1. Number of publications per year and cumulative sum. Note. The figure represents a graph of the number of publications per year and cumulative sum of them. On the horizontal axis, it represents years from 2000 to 2016 with Step 1 (shows only the years that there were publications). On the vertical axis on the left - Numbers from 0 to 7 with Step 1; Vertical on the right - Numbers from 0 to 20 with Step 2; Bars - Number of publications per year; Line Cumulative number of publications up to the corresponding year. The results are as explained in the Data Analyses part of the Methodology.

As for type of materials, there were 6 book chapters, 11 papers and 1 working paper. Among the 18 publications, 15 were about Japan only, 2 others were comparison between Japan and Germany and 1 study about Japan and South Korea.

For methodology, there were four qualitative studies, consisting of interviews, case study, multiple-case study and multi-level case study; there were eight conceptual publications and six empirical publications.

\footnotetext{
${ }^{2}$ For the systematic review protocol, see Appendix A.
} 
We conducted content analysis of each paper, as we described above and tabulated the results according to authors/year; type of material; methodology; country; concepts mentioned in the publication (these are not keywords used by the authors but concepts in connection to our topic); and in the end topic of the paper as described by the author/s. More details can be seen in Table 1 .

Table 1

Core Topics Examined in the Field

\begin{tabular}{|c|c|c|c|c|c|c|}
\hline No. & Author/year & \begin{tabular}{|l|} 
Type of \\
material
\end{tabular} & Methodology & Country & Concepts mentioned* & Topic \\
\hline 1 & $\begin{array}{l}\text { Ahmadjian } \\
(2000)\end{array}$ & $\begin{array}{l}\text { Book } \\
\text { chapter }\end{array}$ & $\begin{array}{l}\text { Qualitative - } \\
\text { interviews }\end{array}$ & Japan & \begin{tabular}{|l|} 
Executives \\
compensation, Board of \\
Directors, Kansayaku, \\
commercial code
\end{tabular} & $\begin{array}{l}\text { This chapter has examined changes in } \\
\text { executive compensation and board structure } \\
\text { of Japan in the 1990s. }\end{array}$ \\
\hline 2 & $\begin{array}{l}\text { Learmount } \\
(2002)\end{array}$ & $\begin{array}{l}\text { Book } \\
\text { chapter }\end{array}$ & Empirical & Japan & $\begin{array}{l}\text { Board of Directors, } \\
\text { external directors, } \\
\text { board of auditors, } \\
\text { decision-making }\end{array}$ & $\begin{array}{l}\text { In this chapter, the author presents his } \\
\text { analysis of the role of senior management (he } \\
\text { uses this term to include directors, senior } \\
\text { directors, and corporate auditors) in the } \\
\text { governance of the companies he studied. }\end{array}$ \\
\hline 3 & Dore (2003) & Paper & Conceptual & Japan & $\begin{array}{l}\text { Board of directors, } \\
\text { internal controls, } \\
\text { external controls } \\
\end{array}$ & $\begin{array}{l}\text { Different preconditions for effectiveness, } \\
\text { affected by national cultures and employment } \\
\text { systems. }\end{array}$ \\
\hline 4 & $\begin{array}{l}\text { Ahmadjian } \\
\text { and Song } \\
(2004)\end{array}$ & Paper & Case study & \begin{tabular}{|l} 
Japan and \\
South \\
Korea
\end{tabular} & $\begin{array}{l}\text { Commercial code, } \\
\text { accounting reform, } \\
\text { Kansayaku }\end{array}$ & $\begin{array}{l}\text { Results of Anglo-American corporate } \\
\text { governance in Japan and South Korea. }\end{array}$ \\
\hline 5 & Dore (2005) & Paper & Conceptual & $\begin{array}{l}\text { Japan and } \\
\text { Germany }\end{array}$ & \begin{tabular}{|l|} 
Internal controls, \\
external controls, \\
statutory auditors, CEO
\end{tabular} & $\begin{array}{l}\text { Differences in national value systems lead to } \\
\text { different preferences regarding outcomes in } \\
\text { the "who gets what" dimension. }\end{array}$ \\
\hline 6 & $\begin{array}{l}\text { Jackson and } \\
\text { Moerke (2005) }\end{array}$ & Paper & Conceptual & $\begin{array}{l}\text { Japan and } \\
\text { Germany }\end{array}$ & $\begin{array}{l}\text { Board of directors, CEO, } \\
\text { insider management }\end{array}$ & $\begin{array}{l}\text { This article provides an introductory } \\
\text { overview and analysis by comparing recent } \\
\text { developments in corporate law reform, } \\
\text { banking and finance, and employment in } \\
\text { Germany and Japan. }\end{array}$ \\
\hline 7 & $\begin{array}{l}\text { Kurihama } \\
(2005)\end{array}$ & Paper & Conceptual & Japan & $\begin{array}{l}\text { Independent auditing, } \\
\text { internal auditing, } \\
\text { auditing of corporate } \\
\text { auditors, } \\
\text { decision-making }\end{array}$ & $\begin{array}{l}\text { This paper clarifies the issues and future } \\
\text { challenges that Japanese corporations are } \\
\text { facing through discussion of corporate social } \\
\text { responsibility (CSR) in Japan. And it also } \\
\text { clarifies the relationship between CSR, } \\
\text { corporate governance, and auditing in Japan } \\
\text { while it examines the concept of auditing as } \\
\text { corporate auditing. }\end{array}$ \\
\hline 8 & $\begin{array}{l}\text { Ahmadjian } \\
\text { and Okumura } \\
(2006)\end{array}$ & $\begin{array}{l}\text { Book } \\
\text { chapter }\end{array}$ & Empirical & Japan & $\begin{array}{l}\text { Board of directors, } \\
\text { decision-making, } \\
\text { Commercial Code, } \\
\text { Kansayaku } \\
\end{array}$ & $\begin{array}{l}\text { Transformation process of corporate } \\
\text { governance in Japan since the 1990s. }\end{array}$ \\
\hline 9 & $\begin{array}{l}\text { Buchanan and } \\
\text { Deakin (2007) }\end{array}$ & $\begin{array}{l}\text { Working } \\
\text { paper }\end{array}$ & $\begin{array}{l}\text { Multiple case } \\
\text { study - } \\
\text { interviews }\end{array}$ & Japan & $\begin{array}{l}\text { Board of directors, } \\
\text { outside directors, } \\
\text { corporate auditors, } \\
\text { governance reform, } \\
\text { decision-making } \\
\end{array}$ & $\begin{array}{l}\text { The objective of the research is to investigate } \\
\text { how far the polarized view of "traditionalists" } \\
\text { versus "modernizers" was borne out at firm } \\
\text { level. }\end{array}$ \\
\hline 10 & Dore (2007a) & Paper & Conceptual & Japan & \begin{tabular}{|l|} 
Board of directors, \\
executive officers, \\
external directors, \\
advisory board, \\
company law, \\
decision-making process \\
\end{tabular} & $\begin{array}{l}\text { Corporate governance reform after Company } \\
\text { law. Specifics of Japanese corporate culture. }\end{array}$ \\
\hline
\end{tabular}


(Table 1 continued)

\begin{tabular}{|c|c|c|c|c|c|c|}
\hline No. & Author/year & $\begin{array}{l}\text { Type of } \\
\text { material }\end{array}$ & Methodology & Country & Concepts mentioned* & Topic \\
\hline 11 & Dore (2007b) & $\begin{array}{l}\text { Book } \\
\text { chapter }\end{array}$ & Conceptual & Japan & $\begin{array}{l}\text { Decision-making } \\
\text { process, Board of } \\
\text { directors, CEO, } \\
\text { Corporate Law, insider } \\
\text { management }\end{array}$ & $\begin{array}{l}\text { What constitutes "good" corporate governance, } \\
\text { and what subjecting managers to thorough and } \\
\text { transparent external monitoring has to do with } \\
\text { it. The legal and organizational changes } \\
\text { affecting the governance structure of Japanese } \\
\text { firms over the last decade, many of which have } \\
\text { aimed to increase the intensity of external } \\
\text { monitoring, have had very limited effect on } \\
\text { promoting "good" corporate governance. }\end{array}$ \\
\hline 12 & $\begin{array}{l}\text { Kurihama } \\
(2007 a)\end{array}$ & Paper & Conceptual & Japan & Independent auditing & $\begin{array}{l}\text { This paper clarifies the relationship between } \\
\text { Corporate Social Responsibility (CSR), } \\
\text { corporate governance and auditing, and } \\
\text { reexamines a role for auditing in CSR and } \\
\text { corporate governance through the discussion } \\
\text { of the relationship between corporations and } \\
\text { society as recently brought up concerning } \\
\text { CSR. }\end{array}$ \\
\hline 13 & $\begin{array}{l}\text { Kurihama } \\
\text { (2007b) }\end{array}$ & Paper & Conceptual & Japan & Independent auditing & $\begin{array}{l}\text { This paper clarifies a new perspective on } \\
\text { relationship between corporate governance } \\
\text { and independent auditing, and reexamines the } \\
\text { contribution of independent auditing to } \\
\text { corporate governance through the discussion } \\
\text { of the relationship between corporations and } \\
\text { society as recently brought up concerning } \\
\text { CSR. }\end{array}$ \\
\hline 14 & $\begin{array}{l}\text { Yoshikawa } \\
\text { et al. (2007) }\end{array}$ & Paper & $\begin{array}{l}\text { A multiple-case, } \\
\text { multiple-level } \\
\text { study }\end{array}$ & Japan & $\begin{array}{l}\text { Board of directors, } \\
\text { outside directors }\end{array}$ & $\begin{array}{l}\text { This paper analyzes the diffusion of } \\
\text { governance innovation in Japan. }\end{array}$ \\
\hline 15 & $\begin{array}{l}\text { Chizema and } \\
\text { Shinozawa } \\
(2012)\end{array}$ & Paper & Empirical & Japan & $\begin{array}{l}\text { Conventional auditor } \\
\text { system, committee } \\
\text { system }\end{array}$ & $\begin{array}{l}\text { This paper examines the adoption of the } \\
\text { committee-based governance system (i.e., } \\
\text { audit, nomination, and remuneration) in } \\
\text { Japanese firms, a practice common in } \\
\text { Anglo-American capitalism but potentially } \\
\text { contestable in Japan. }\end{array}$ \\
\hline 16 & Dore (2013) & $\begin{array}{l}\text { Book } \\
\text { chapter }\end{array}$ & Empirical & Japan & $\begin{array}{l}\text { Decision-making } \\
\text { process, Board of } \\
\text { directors, CEO }\end{array}$ & $\begin{array}{l}\text { The chapter is devoted to describing and } \\
\text { seeking to explain the changes themselves - } \\
\text { the changes in corporate governance broadly } \\
\text { conceived - that have very substantially } \\
\text { altered the "Japanese-style management" } \\
\text { which American business schools discovered } \\
\text { and celebrated in the 1980s. }\end{array}$ \\
\hline 17 & Miwa (2015) & $\begin{array}{l}\text { Book } \\
\text { chapter }\end{array}$ & Empirical & Japan & $\begin{array}{l}\text { Board of directors, } \\
\text { outside directors, } \\
\text { statutory auditors, } \\
\text { decision-making }\end{array}$ & $\begin{array}{l}\text { This chapter examines the reason why the } \\
\text { managers of Japanese companies are reticent } \\
\text { about appointing outside directors, despite } \\
\text { strong pressure from foreign investors to make } \\
\text { such appointments. Also, it empirically } \\
\text { examines the relationship between the } \\
\text { appointment of outside directors and the } \\
\text { performance of Japanese companies that are } \\
\text { listed on the First Section of the Tokyo Stock } \\
\text { Exchange (TSE). }\end{array}$ \\
\hline 18 & $\begin{array}{l}\text { Geng et al. } \\
(2016)\end{array}$ & Paper & Empirical & Japan & Managers & $\begin{array}{l}\text { The paper examines the reason why Japanese } \\
\text { firms have adopted executive stock option } \\
\text { pay, which was developed with } \\
\text { shareholder-oriented institutional logic that } \\
\text { was inconsistent with Japanese } \\
\text { stakeholder-oriented institutional logic. }\end{array}$ \\
\hline
\end{tabular}

Note. ${ }^{*}$ The concepts mentioned are not keywords used by the authors but concepts in connection to our topic in this review paper. 
After that, we examined in more detail the concepts mentioned in the publications and calculated the number and percent spread of each of them, organized around main groups. In Table 2, we can see how in 11 publications are mentioned Board of directors, 5 of which are about outside directors. There are 7 publications about management structure, 11 for type of auditors, 5 for regulatory acts, 2 for type of reform, 2 for corporate governance mechanism and 10 for processes. We are showing the different variations of the same concepts in the way they were used in the original sources, for example, outside directors - external directors; or insider management, management, executive officers; or Board of auditors, statutory auditors, Kansayaku, etc.

Table 2

Number and Percent Spread of Concepts Mentioned in the Publications Used for the Analysis

\begin{tabular}{|c|c|c|}
\hline Concepts mentioned & Number & Percent (\%) \\
\hline Board of directors & 11 & 61 \\
\hline Outside directors & 5 & 28 \\
\hline Outside directors & 3 & 60 \\
\hline External directors & 2 & 40 \\
\hline Management structure & 7 & 39 \\
\hline CEO & 4 & 57 \\
\hline Insider management & 2 & 29 \\
\hline Managers & 1 & 14 \\
\hline Executive officers & 1 & 14 \\
\hline Executives compensation & 1 & 14 \\
\hline Advisory board & 1 & 14 \\
\hline Type of auditors & 11 & 61 \\
\hline Board of auditors & 1 & 9 \\
\hline Conventional auditor system, committee system & 1 & 9 \\
\hline Corporate auditors & 2 & 18 \\
\hline Independent auditing & 3 & 27 \\
\hline Internal auditing & 1 & 9 \\
\hline Kansayaku & 3 & 27 \\
\hline Statutory auditors & 2 & 18 \\
\hline Regulatory act & 5 & 28 \\
\hline Commercial code & 3 & 60 \\
\hline Company law & 1 & 20 \\
\hline Corporate law & 1 & 20 \\
\hline Type of reform & 2 & 11 \\
\hline Accounting reform & 1 & 50 \\
\hline Governance reform & 1 & 50 \\
\hline Corporate governance mechanism & 2 & 11 \\
\hline Internal controls, external controls & 2 & 100 \\
\hline Process & 10 & 56 \\
\hline Decision-making & 10 & 100 \\
\hline Information processing - formal, informal meetings & 2 & 20 \\
\hline Information processing between managers and share/stakeholders & 2 & 20 \\
\hline Total number of papers & 18 & 100 \\
\hline
\end{tabular}




\section{Discussion}

The topic for involvement of board directors in the decision-making process has been the point of discussion for a long time in USA. As Westphal (1998) identified, not only do they (board directors) have limited (if any) exposure to the day-to-day decision-making of managers, but they also typically lack the firm-specific knowledge and/or industry knowledge possessed by insiders. According to the author, such extreme information and knowledge asymmetries provide fertile ground for interpersonal influence behavior.

From our findings, we can assume that in the early 2000s even insider board directors in Japanese companies did not take an active part in the decision-making process. As Learmount (2002) stated, the decision-making power is concentrated in the hands of a small executive management committee. A few years later, Jackson and Moerke (2005) in their comparison between Japanese and German corporate governance are sharing Kubo's idea that a post on the Board of Directors is indeed a part of the career path in Japan, and the task of a director is to motivate the employees rather than maximize shareholder value. Therefore, insider directors are present on the Board as a result of loyalty to the company (a point we showed in the beginning of the study) but they have neither monitoring nor decision-making role.

Another study on the topic by Dore (2007a) discusses some changes in the Board structure and in this way introduces the appointment of two or three outside directors. According to the author, neither of "these changes made the decision-making more efficient, speedier or less likely to lead to illegal or anti-social enterprise behavior" (p. 209). But what is the reason for the lack of results?

The same author this time in a book chapter provides some options for an answer to this question. He showed how outside directors in Japanese companies encounter difficulties to play an active role during the formal meetings in the board room because:

The real discussions and decisions still take place in informal meetings at which the outside directors are absent. How much the outside directors can subsequently contribute at the formal board meeting depends on how much information they are given. In one firm they are always visited beforehand to receive background information on the items to be presented at the next board meeting. But as one outside complained, this merely wastes his time since the background explanation consists of exactly what is related at the board meeting as the reasons for taking a particular decision, whereas what he wants to know, and is never told, are what were the counter arguments raised in internal discussions and why they were rejected (Dore, 2007b, p. 382).

These ideas are drawn further by Buchanan and Deakin (2007), who discussed in their multiple-case study conducted by interviews, how outside directors had often been described as isolated within the (Japanese) companies in which they held office. They were often treated as advisers and the view that the Executive Board should be running the business persists. As a main reason for this, the authors pointed out that these people have not worked for the CEO. They gave an example with one of the companies that they held interviews in that he (the $\mathrm{CEO}$ ) and his internal directors met once every two weeks for a discussion of major business and administration issues without involving their outside colleagues. The different stages of corporate governance reforms in connection to efficient decision-making are discussed by Dore (2013) in his conceptual paper, where he showed most of the options that we have already mentioned above and added the creation of an Advisory Board, usually of outsiders, which may be given a variety of powers including the monitoring of appointments and executive compensation but this is given as an example from only one company. The latest research (Miwa, 2015) also ascertained that managers expect outside directors to function as supervisors of management, but do not necessarily require them to be involved in managerial decision-making. This shows that for the course of more than a decade, despite all changes and reforms, the role of board directors, whether insiders or outsiders, is still supplementary. 
In order to take part in these discussions and make the decision-making more effective, outside directors need information. The question is how to obtain this information? Where from and with the help of whom? Another point is that they need time - as served tenure on the Board after which they can be considered as ones who had "worked" for the CEO and as a part of the closed circle of insiders.

Another difficulty for outside board members about expressing freely their opinion and contributing to the decision-making process is the powerful figure of the CEO. Boivie et al. (2016) pointed out the CEO power as one of the group factors that creates barriers for Board of Directors in fulfilling their roles. This is even more essential in Japanese reality where insiders in the Board are with life-long careers at that company and have been part of each and every level of the hierarchy till they reached the posts of board members. In contrast to this, Garg and Eisenhardt (2016) in their study, based on interviews taken from CEOs and board directors, explored effective discussions during strategy-making process with one-on-one meetings between the CEO and each director outside the board room (informal meetings), and focused debate on a single formal strategy alternative inside the board room (formal meetings). They showed that better results are achieved also by CEOs who use external and internal personal alliances - political action. One reason for its effectiveness is that political action can unexpectedly yield creative advice from board members at late stages of the strategy-making process. Again, this confirms that forming social ties between the outside board directors and CEO can help the decision-making process.

We consider as one of the major inside sources of information for better decision-making, the Audit \& Supervisory (Kansayaku) Board because as Kurihama (2005) mentioned in his study about the relationship between corporate governance in Japan and independent auditing, in the light of CSR, "auditing as an institution enables the users to secure autonomy as well as freedom in their decision-making” (p. 13).

As we mentioned above, the Audit \& Supervisory Board is a feature of the Japanese corporate governance system. According to the Corporate Governance Code (2015), they audit the performance of duties by directors and the management and have investigation power by law. In previous studies, the Audit \& Supervisory Board position is described like a consolation prize for those unable to attain board membership (Ahmadjian \& Song, 2004) and again as ex-directors or ex-employees who fell just short of becoming directors (Dore, 2005). Thus, we can suggest that they have a lower status than the board directors, just like the newly appointed outside directors. But at the same time, they are insiders who have worked with the CEO through the course of their entire career and possess all the information for the company because of the position they held. As Kurihama (2007a, p. 112) identified, "the commitment of managers and the monitoring and check of managers' decision-making and behaviors is very important”. And he continues:

For example, today, it is necessary for Japanese corporate auditors (Kansayaku) to fulfill their duties with a basic viewpoint to the establishment and operation of the system of good corporate governance. And, it is desirable for corporate auditors to prevent corporate misdeeds and scandals and to ensure and safeguard sustained growth and development of their corporation as their fundamental duties. The main scope of activity of corporate auditors is "audit of director's performance of duties", "audit of decision-making of board of directors", "audit of status of internal control systems", “monitoring of independent auditors”, and “audit of financial reporting system” (Kurihama, 2007a, pp. 116-117).

Therefore, we can assume that it will be easier for the outsiders to establish contacts and form social ties with the Audit \& Supervisory Board members because of their unspoken lower status and thus to obtain more information about the company internal affairs and discussions that take place during the informal meetings. As we could observe, the statutory auditors are performing “audit of decision-making of board of directors" which means that they possess all the information for the steps taken in the process of reaching to every decision. 


\section{Model of Information Processing}

We took as a basis the model of Garg and Eisenhardt (2016), about the Emergent Framework of Board-level Strategy-Making Process in Ventures. We changed the explanation of the types of meetings between the different players at the top in order to meet the Japanese companies' style of communication; for the time line, we used as a beginning the appointment of outside board members for the first time; and we showed that the elements of this type of communication lead to positive results in the effectiveness in the decision-making process. In this way, we reached to our model type about the information exchange flow of board-level decision-making process in Japanese companies (see Figure 2).

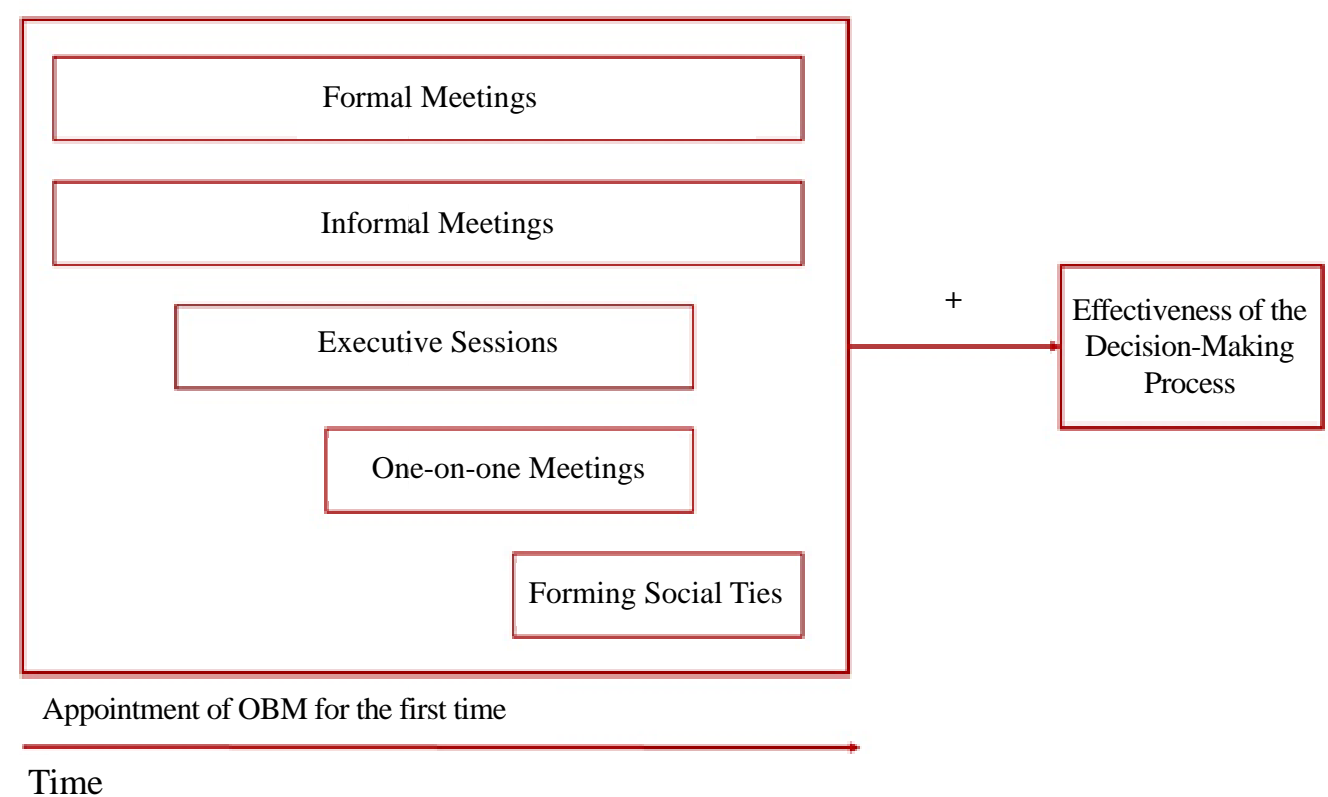

Figure 2. Information exchange flow of board-level decision-making process in Japanese companies. Note. Figure 2 represents the information exchange flow of board-level decision-making process in Japanese companies as described in the Discussion - Model of Information Processing part of this paper. The figure shows a big rectangle with five smaller rectangles placed horizontally in it. They have some space between each other. The first two rectangles are almost as wide as the big rectangle and they represent the "formal" and "informal meetings", respectively. The third rectangle is a little bit narrower than the first two and states for "executive sessions". The fourth rectangle is narrower than the third one but its right side is on one line with it. It shows "one-on-one meetings". Then the fifth one for "forming social ties" starts from the middle of the fourth and its right side is a little bit to the right. The big rectangle has a short arrow, attached in the middle of its right side that points towards a smaller rectangle called "effectiveness of the decision-making process". Above the arrow, there is a "plus" sign. Under the big rectangle, there is a long arrow - under it on the left there is a sign stating "time" and over it another one with smaller font called "appointment of outside board members for the first time". The point of the arrow finishes at the right side of the big rectangle but does not "touch" or overlap with it.

Additionally, we made a more detailed explanation about the information flow between the different types of players at the top and the types of meetings they interact in. As it is shown in Figure 3, outside board members can interact with all other top management team members: CEO, insider board members and Audit \& Supervisory Board (Kansayaku) members, during the formal board meetings. They can also organize other formal executive meetings only among outside board members. Eventually, Audit \& Supervisory Board members can take part in them too. CEO on his side takes part in informal meetings with inside board members 
during these meetings the real decisions are made and after that they are just approved during the formal board meetings, where the outside board directors are present. In order to avoid this asymmetry of information, each outside board director can have a supplementary one-on-one meeting with the CEO and give his professional advice on the discussed topics. Forming social ties between the CEO and outside board directors can lead to better communication and higher involvement of the newly appointed board members in the decision-making process.

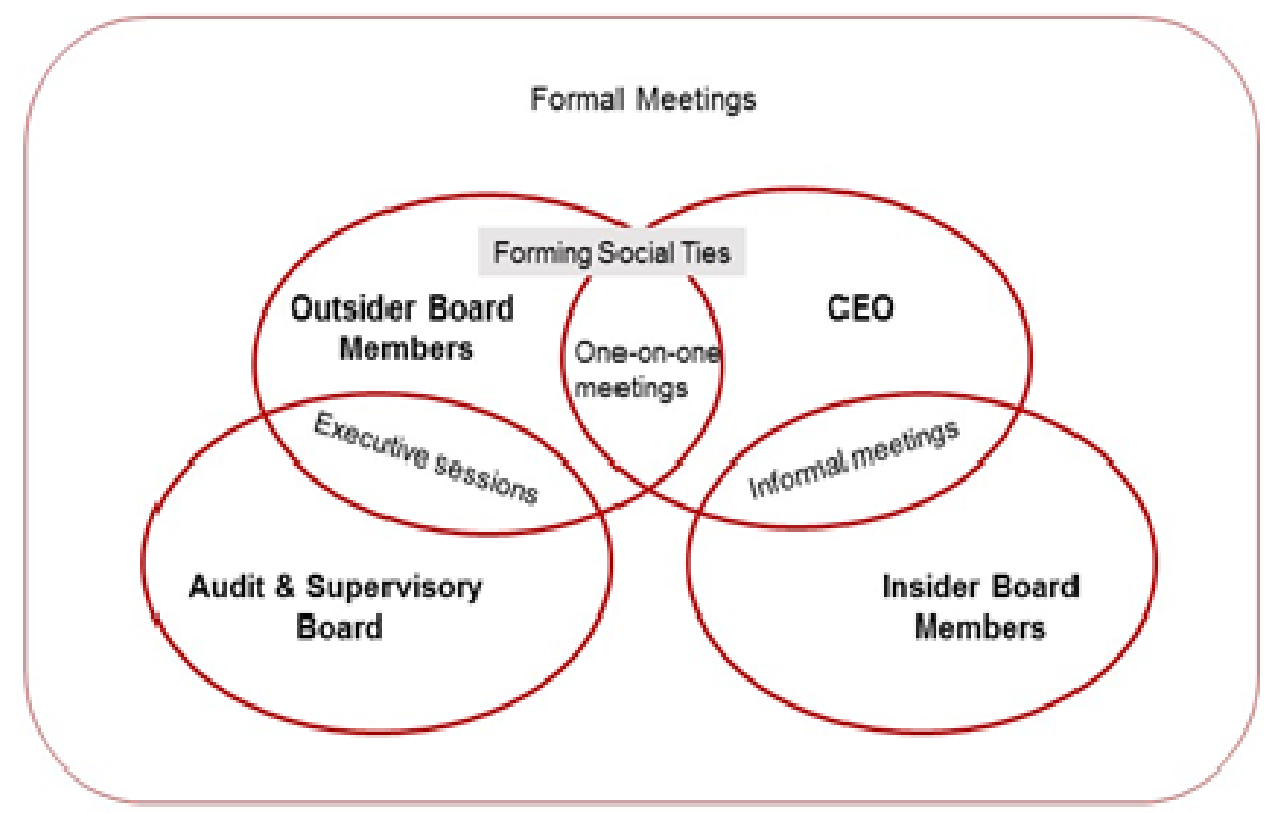

Figure 3. Players at the top and types of meetings they interact in. Note. Figure 3 represents players at the top and types of meetings they interact in. It shows a big rectangle with rounded edges that has sign inside on the top "formal meetings". Under the sign, there are four ellipses. The top left ellipse is for "outside board members", which overlaps to the right with the top right ellipse - "CEO". Inside the overlapping space, there is a sign "one-on-one meetings". Over it crossing the overlapping space and reaching to the left and right the two ellipses, there is a small rectangle that is called "forming social ties". The bottom left ellipse - "Audit \& Supervisory Board", overlaps with the "outside board members" ellipse and the space that is formed between them is called "executive sessions". The lower right ellipse - "insider board members", overlaps with the "CEO" ellipse and the overlapping part is called "informal meetings". The "Audit \& Supervisory Board" ellipse does not overlap with the "insider board members” one. The description of the interaction of the top players and the types of meetings is described in the Discussion - Model of Information Processing part.

\section{Conclusion}

Recent changes of corporate governance course in Japan set some important questions about the presence and the role of the outside board members in the board room. We consider the decisions that Board of Directors have to take and the difficulties the newly introduced outside board members encounter in their attempts to effectively communicate with the insiders for the company. Our paper examines how outside directors in Japanese boards obtain information to take part in decision-making process. We offer ways of better communication between the sides of insiders and outsiders and one of these options is close cooperation with Kansayaku board. 
Out study contributes to extant literature in several ways:

First, we use Behavioral Theory in connection of the Japanese Corporate Governance Code enactment. Cuomo et al. (2016) in their review of Corporate Governance Codes mentioned that the Agency theory is mostly used by authors, followed by institutional theory. Other theories (e.g., stakeholder theory, political theory, efficiency theory, stewardship theory, contingency theory, conflict and signaling theories, and financial system theory) are rarely adopted. Behavioral theory in connection to corporate governance codes is not mentioned at their work. This is a new element that can be explored in more detail with empirical or case study in the future.

Second, we use a behavioral perspective on the CEO-board relationship that is less atomistic, more dynamic, and focused on firm performance (Garg \& Eisenhardt, 2016), in the context of Japanese reality. We show the Board of Directors-CEO relations from a new perspective that is typical only for Japan. Here, the insiders group of board members includes the CEO and the top management team, so that the relations are between this group and the outside board members.

Third, we explain in the context of Japanese corporate governance the role of the Board directors as participants in the decision-making process. Since in Japan which has community-like corporations, the effective mechanisms which impose discipline on those who manage corporations can be not external at all, but internal (Dore, 2003). Provided that monitoring is executed by inside forces, the outside directors have a helping function: advice and resource provision role.

Fourth, we explore the role of the Kansayaku board as an information provider for newly appointed outside board directors.

Our review paper has some limitations. Firstly, it is based on extant literature in English only. Some of the sources written in Japanese have been taken like citations as parts of other English papers. Secondly, the enactment of the Corporate Governance Code is too recent and the changes following it are going to be examined more thoroughly in the years to come. Finally, other inside company members' groups can be also considered as an important source of information and collaboration with outside board members.

Our study opens an agenda for future research. A case study and/or empirical research can be conducted in order to explore in more detail the information flow between insider and outsider board members; and the internal and external sources of information that can help the Board of Directors to reach the best decisions for the companies' stability and growth. Another point to be explored empirically in the future is the executive sessions between the outside board members and the Audit \& Supervisory Board. As we showed in our study this type of communication has not been subject of the existing research literature.

\section{References}

Ahmadjian, C. L. (2000). Chapter 9. Changing Japanese corporate governance. The Japanese Economy, 28(6), 59-84.

Ahmadjian, C. L., \& Okumura, A. (2006). Corporate governance in Japanese banks. In C. A. Mallin (Ed.), Handbook on international corporate governance: Country analyses (pp. 130-147). Cheltenham, UK: Edward Elgar Publishing.

Ahmadjian, C. L., \& Song, J. (2004). Corporate governance reform in Japan and South Korea: Two paths of globalization. Columbia University Academic Commons. Retrieved from http://hdl.handle.net/10022/AC:P:222

Boivie, S., Bednar, M. K., Aguilera, R. V., \& Andrus, J. L. (2016). Are boards designed to fail? The implausibility of effective board monitoring. The Academy of Management Annals, 10(1), 319-407.

Buchanan, J., \& Deakin, S. (2007). Japan's paradoxical response to the new "global standard” in corporate governance. ECGI Law Working Paper No. 87/2007. Retrieved from https://ssrn.com/abstract=1013286 or http://dx.doi.org/10.2139/ssrn.1013286 
Carpenter, M. A., \& Westphal, J. D. (2001). The strategic context of external network ties: Examining the impact of director appointments on board involvement in strategic decision making. Academy of Management Journal, 4(4), 639-660.

Chizema, A., \& Shinozawa, Y. (2012). The 'Company with committees': Change or continuity in Japanese corporate governance? Journal of Management Studies, 49(1), 77-101.

Cuomo, F., Mallin, C., \& Zattoni, A. (2016). Corporate governance codes: A review and research agenda. Corporate Governance: An International Review, 24(3), 222-241.

Del Brio, E. G., Yoshikawa, T., Connelly, C. E., \& Tan, W. L. (2013). The effects of CEO trustworthiness on directors' monitoring and resource provision. Journal of Business Ethics, 118(1), 155-169.

Dewey, M. E. (1983). Coefficients of agreement. British Journal of Psychiatry, 143(5), 487-489.

Dore, R. (2003). The globalization of corporate governance: External and internal mechanisms of control. The Journal of Interdisciplinary Economics, 14(2), 125-137.

Dore, R. (2005). Deviant or different? Corporate governance in Japan and Germany. Corporate Governance: An International Review, 13(3), 437-446.

Dore, R. (2007a). Shareholder capitalism comes to Japan. ZeitschriftfürJapanischesRecht, No. 23, pp. 207-214.

Dore, R. (2007b). Insider management and board reform: For whose benefit? In M. Aoki, G. Westphal, \& H. Miyajima (Eds.), Corporate governance in Japan institutional change and organizational diversity (pp. 370-395). Oxford: Oxford University Press.

Dore, R. (2013). The residual Japaneseness of Japanese corporate governance. In H. Magara, \& S. Sacchi (Eds.), The politics of structural reforms: Social and industrial policy change in Italy and Japan. Cheltenham: Edward Elgar.

Garg, S., \& Eisenhardt, K. M. (2016). Unpacking the CEO-Board relationship in entrepreneurial firms. Academy of Management Journal, published ahead of print September 12, 2016.

Geng, X., Yoshikawa, T., \& Colpan, A. (2016). Leveraging foreign institutional logic in the adoption of stock option pay among Japanese firms. Strategic Management Journal, 37(7), 1472-1492.

Jackson, J., \& Moerke, A. (2005). Continuity and change in corporate governance: Comparing Germany and Japan. Corporate Governance: An International Review, 13(3), 351-361.

Janssen, M. A., Schoon, M. L., Ke, W., \& Börner, K. (2006). Scholarly networks on resilience, vulnerability and adaptation within the human dimensions of global environmental change. Global Environmental Change, 16(3), 240-252.

Khanna, P., Jones, C. D., \& Boivie, S. (2014). Director human capital, information processing demands, and board effectiveness. Journal of Management, 40(2), 557-585.

Kurihama, R. (2005). Corporate social responsibility, corporate governance and auditing in Japan. Asia in Extenso (online publication), March 1-17.

Kurihama, R. (2007a). Role for auditing in corporate social responsibility and corporate governance: Under new corporate view. Corporate Ownership and Control, 5(1), 109-119.

Kurihama, R. (2007b). A new perspective on relationship between corporate governance and auditing. Issues in Social and Environmental Accounting, 1(2), 258-275.

Learmount, S. (2002). Japanese directors - elders of the corporate community. In Corporate governance. What can be learned from Japan (pp. 125-143)? New York, NY: Oxford University Press.

Miwa, S. (2015). Empirical analysis of the influence of outside directors on Japanese firm performance. In N. Kambayashi (Ed.), Japanese management in change: The impact of globalization and market principles (pp. 35-50). Tokyo, Springer Japan.

Nowak, M. J., \& McCabe, M. (2003). Information costs and the role of the independent corporate director. Corporate Governance: An International Review, 11(4), 300-307.

Pugliese, A., Bezemer, P. J., Zattoni, A., Huse, M., Van der Bosch, F. A. J., \& Volberda, H. W. (2009). Boards of directors' contribution to strategy: A literature review and research agenda. Corporate Governance: An International Review, 17(3), 292-306.

Shen, W., \& Cannella Jr, A. A. (2002). Revisiting the performance consequences of CEO succession: The impacts of successor type, postsuccession senior executive turnover, and departing CEO tenure. The Academy of Management Journal, 45(4), 717-733.

The Council of Experts Concerning the Corporate Governance Code. (2015). Japan's corporate governance code: Seeking sustainable corporate growth and increased corporate value over the mid- to long-term. Retrieved from http://www.fsa.go.jp/en/refer/councils/corporategovernance/20150306-1/01.pdf 
Tranfield, D., Denyer, D., \& Smart, P. (2003). Towards a methodology for developing evidence-informed management knowledge by means of systematic review. British Journal of Management, 14(3), 207-222.

Walsh, J. P., \& Seward, J. K. (1990). On the efficiency of internal and external corporate control mechanisms. Academy of Management Review, 15(3), 421-458.

Westphal, J. D. (1998). Board games: How CEOs adapt to increases in structural board independence from management. Administrative Science Quarterly, 43(3), 511-537.

Westphal, J. D., \& Zajac, E. J. (1995). Who shall govern? CEO/Board power, demographic similarity, and new director selection. Administrative Science Quarterly, 40(1), 60-84.

Westphal, J. D., \& Zajac, E. J. (2013). A behavioral theory of corporate governance: Explicating the mechanisms of socially situated and socially constituted agency. Academy of Management Annals, 7(1), 607-661.

Yoshikawa, T., Tsui-Auch, L. S., \& McGuire, J. (2007). Corporate governance reform as institutional innovation: The case of Japan. Organization Science, 18(6), 973-988. 
Appendix A: A Systematic Review Protocol

0. Identification for the need of a review

0.1. Holistic evaluation of decision-making in Japanese boards and outside directors obtaining information to take part in it

0.1.1. Seed papers

We identified the seed papers group by choosing from literature that we were personally familiar with. We also asked for suggested literature by our academic contact list, composed by leading scholars in the area of corporate governance, especially in the Phase 0: Asian region and Japan in particular.

Identification

0.1.2. Keywords

We extracted keywords from the seed papers and other papers in identification the field, allocated by their reference list.

0.1.3. Reason

To allocate the other actors of interaction with Board of Directors in the present literature, except the CEO.

0.1.4. Source for the approach

Janssen et al. (2006)

0.2. Identification of the reason why a systematic review might contribute to literature on information processing in Japanese boards

\begin{tabular}{|c|c|c|c|}
\hline Elements & Review proposal & \multirow{4}{*}{$\begin{array}{l}\text { Phase 1: } \\
\text { Preparation of a } \\
\text { proposal for a } \\
\text { review }\end{array}$} & \multirow{15}{*}{$\begin{array}{l}\text { Stage I: } \\
\text { Planning the } \\
\text { review }\end{array}$} \\
\hline Title & $\begin{array}{l}\text { Decision-Making Process in Japanese Board Room. Audit \& } \\
\text { Supervisory Board as a Source of Information to Outside Board } \\
\text { Members: A Systematic Review }\end{array}$ & & \\
\hline Research question & $\begin{array}{l}\text { This paper identifies the development of and gaps in knowledge in } \\
\text { business and management research on how outside directors in } \\
\text { Japanese boards obtain information to take part in } \\
\text { decision-making process. }\end{array}$ & & \\
\hline Type of review & Systematic review & & \\
\hline \multicolumn{2}{|l|}{ Methodology } & \multirow{11}{*}{$\begin{array}{l}\text { Phase 2: } \\
\text { Development of } \\
\text { a review } \\
\text { protocol }\end{array}$} & \\
\hline \multicolumn{2}{|l|}{ 1. Methodological steps } & & \\
\hline \multicolumn{2}{|l|}{ 1.1. Sources followed } & & \\
\hline 1.1.1. For the methodology & Tranfield et al. (2003); Pugliese et al. (2009); Cuomo et al. (2016) & & \\
\hline 1.1.2. For the topic itself & Boivie et al. (2016); Khanna et al. (2014) & & \\
\hline $\begin{array}{l}\text { 1.1.3. For literature analyses } \\
\text { and codifying }\end{array}$ & Tranfield et al. (2003); Pugliese et al. (2009); Cuomo et al. (2016) & & \\
\hline \multicolumn{2}{|l|}{ 1.2. Steps - general overview } & & \\
\hline 1.2.1. First step & Compilation of a comprehensive data set of relevant publications & & \\
\hline 1.2.2. Second step & Cleaning of the data & & \\
\hline 1.2.3. Third step & $\begin{array}{l}\text { Analyzing the literature and codifying previous studies on Japanese } \\
\text { corporate governance using the following criteria: author/year; type } \\
\text { of material - article, book, book chapter; methodology; country; } \\
\text { concepts mentioned in connection to our topic; topic }\end{array}$ & & \\
\hline 1.2.4. Fourth step & $\begin{array}{l}\text { Finally, for each source identifying the number and percentage of } \\
\text { spread of concepts in connection to our article }\end{array}$ & & \\
\hline \multicolumn{2}{|l|}{ 2. Data collection } & \multirow{13}{*}{ Phase 3: } & \multirow{13}{*}{$\begin{array}{l}\text { Stage II: } \\
\text { Conducting a } \\
\text { review }\end{array}$} \\
\hline 2.1. Type of search & Boolean searches & & \\
\hline 2.2. Citation database & Business Source Complete; Social Sciences Citation Index (SSCI) & & \\
\hline 2.3. Platform & $\begin{array}{l}\text { EBSCOhost; ISI Web of Knowledge (previous Web of Science); } \\
\text { Google Scholar }\end{array}$ & & \\
\hline 2.4. Keywords & 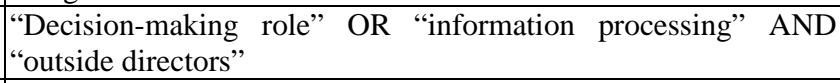 & & \\
\hline 2.5. Searched in & The title, abstracts or keywords (subject terms) & & \\
\hline \multicolumn{2}{|c|}{ 2.6. Limitations of the search } & & \\
\hline 2.6.1. Areas & Business and management research & & \\
\hline 2.6.2. Journals & All journals in the above mentioned databases & & \\
\hline 2.6.3. Type of documents & Articles (only peer-reviewed), books and book chapters & & \\
\hline 2.6.4. Language & English & & \\
\hline 2.6.5. Country & Japan & & \\
\hline 2.7. Search results & 176 & & \\
\hline
\end{tabular}


(Table continued)

3. Data cleaning

\begin{tabular}{|l|l|}
\hline 3.1. Number of reviewers & 2 \\
\hline 3.2.
\end{tabular}

3.2. Determining the suitability for inclusion in the review

\begin{tabular}{|l|l|}
\hline 3.2.1. First check in & The title, abstract, keywords, research purpose or research \\
\hline
\end{tabular}

questions of each record

\begin{tabular}{|l|l|}
\hline 3.2.2. Second check in & If necessary, refer to the full text of the publication \\
\hline
\end{tabular}

Both reviewers agreed that a publication should not be part of the

3.3. Conditions for removal analysis. Cases of disagreement were referred back to both reviewers for re-evaluation

In the first round of cleaning, we removed papers/book chapters focused on different topics or on related topics not relevant to our study (e.g., applicable only for the US or the UK reality or focused only on stock prices dependency; or concerning particular type of

\begin{tabular}{|l|l|} 
3.3.1. First condition & $\begin{array}{l}\text { only on stock prices dependency; or concerning particular type of } \\
\text { industry - banking or automotive), book reviews, duplicates, } \\
\text { company reports, letters from the editors, papers published by } \\
\text { university journals, and student papers. It resulted in } 49 \text { sources } \\
\text { left }\end{array}$ \\
\hline In the second round of cleaning, we refined the data for Japanese
\end{tabular}

\begin{tabular}{|l|l|} 
3.3.1. First condition & $\begin{array}{l}\text { only on stock prices dependency; or concerning particular type of } \\
\text { industry - banking or automotive), book reviews, duplicates, } \\
\text { company reports, letters from the editors, papers published by } \\
\text { university journals, and student papers. It resulted in } 49 \text { sources } \\
\text { left }\end{array}$ \\
\hline In the second round of cleaning, we refined the data for Japanese
\end{tabular}

\begin{tabular}{|l|l|} 
3.3.1. First condition & $\begin{array}{l}\text { only on stock prices dependency; or concerning particular type of } \\
\text { industry - banking or automotive), book reviews, duplicates, } \\
\text { company reports, letters from the editors, papers published by } \\
\text { university journals, and student papers. It resulted in } 49 \text { sources } \\
\text { left }\end{array}$ \\
\hline In the second round of cleaning, we refined the data for Japanese \\
\hline
\end{tabular}

\begin{tabular}{|l|l|} 
3.3.1. First condition & $\begin{array}{l}\text { only on stock prices dependency; or concerning particular type of } \\
\text { industry - banking or automotive), book reviews, duplicates, } \\
\text { company reports, letters from the editors, papers published by } \\
\text { university journals, and student papers. It resulted in } 49 \text { sources } \\
\text { left }\end{array}$ \\
\hline In the second round of cleaning, we refined the data for Japanese
\end{tabular}

In the second round of cleaning, we refined the data for Japanese

3.3.2. Second condition

corporate governance and Auditing \& Supervisory Board (Kansayaku). For that reason, we removed the sources in which the studies have been conducted for other countries except Japan e.g., applicable only for the US or the UK reality or focused only 3.3.3. Example on stock prices dependency; or concerning particular type of industry - banking or automotive

3.4. Results of the cleaning

\begin{tabular}{|l|l|}
\hline 3.4.1. Numbers removed & 158 records \\
\hline 3.4.2. Numbers left & 18 records \\
\hline
\end{tabular}

4. Final sample

\begin{tabular}{|l|l|}
\hline 4.1. Data set & 18 (peer reviewed articles, books and book chapters) \\
\hline 4.2. Publication sources & 17 sources \\
\hline 4.3. Years & Between 2000 and 2016 \\
\hline 4.4. Cut-off & $\begin{array}{l}\text { October } 31,2016, \text { which includes online-first articles published up } \\
\text { to this point }\end{array}$ \\
\hline
\end{tabular}

5. Codifying

\begin{tabular}{|l|l|l|}
\hline 5.1. Sources of the approach & Tranfield et al. (2003); Pugliese et al. (2009); Cuomo et al. (2016) \\
\hline 5.2.
\end{tabular}

5.2. Type of analysis Content analysis

Phase 4:

Selection of

studies

Stage II:

Conducting a review

Phase 5:

(1) Author/year; type of material - article, book, book chapter; Study quality methodology; country; concepts mentioned in connection to our assessment

5.3. Criteria for codifying topic; topic; main findings; (2) For the concepts themselves, we identified additionally the number and percentage spread among the sources

5.4. Coding scheme and the procedure followed

\begin{tabular}{|c|c|c|}
\hline 5.4.1. Preliminary phase & $\begin{array}{l}\text { Two coders initially developed and tested the coding scheme on a } \\
\text { sample of } 6 \text { articles }\end{array}$ & \multirow{4}{*}{$\begin{array}{l}\text { Phase 6: } \\
\text { Data extraction } \\
\text { and monitoring } \\
\text { process }\end{array}$} \\
\hline 5.4.2. First phase & Two different coders codified all the studies independently & \\
\hline 5.4.3. Second phase & $\begin{array}{l}\text { Then, we matched the two sets of data in order to measure } \\
\text { inter-rater reliability using percentage agreement (Dewey, 1983). } \\
\text { We found a high overlap as the percentage agreement was 94\% } \\
\text { and above the appropriate minimum level of reliability }\end{array}$ & \\
\hline 5.4.4. Third phase & $\begin{array}{l}\text { Finally, we met to discuss the few cases where there was a } \\
\text { difference of opinion in order to reach agreement about them }\end{array}$ & \\
\hline
\end{tabular}


(Table continued)

\begin{tabular}{|c|c|c|c|}
\hline \multicolumn{2}{|l|}{ 6. Tables } & \multirow{20}{*}{$\begin{array}{l}\text { Phase 7: } \\
\text { Data synthesis }\end{array}$} & \multirow{20}{*}{$\begin{array}{l}\text { Stage II: } \\
\text { Conducting a } \\
\text { review }\end{array}$} \\
\hline \multicolumn{2}{|l|}{ 6.1. Table 1} & & \\
\hline 6.1.1. Name & Core topics examined in the field & & \\
\hline 6.1.2. Elements & $\begin{array}{l}\text { Columns - author/year; type of material - article/book; } \\
\text { methodology; country; concepts mentioned; topic }\end{array}$ & & \\
\hline \multicolumn{2}{|r|}{$\begin{array}{llll} & 0 \\
\end{array}$} & & \\
\hline 6.2.1. Name & $\begin{array}{l}\text { Number and percent spread of concepts mentioned in the } \\
\text { publications used for the analysis }\end{array}$ & & \\
\hline 6.2.2. Elements & $\begin{array}{l}\text { Columns - concepts mentioned, number, percentage; Rows - } \\
\text { Board of directors, outside directors, CEO, type of auditors, } \\
\text { regulatory act, type of reform, corporate governance mechanism, } \\
\text { process (as main concepts and their derivatives) }\end{array}$ & & \\
\hline \multicolumn{2}{|l|}{ 6.3. Table 3 (Appendix A) } & & \\
\hline 6.3.1. Name & Appendix A: A Systematic Review Protocol & & \\
\hline 6.3.2. Elements & $\begin{array}{l}\text { Columns - elements, review proposal, phases, stages; Rows - } \\
\text { elements of the phases and stages for this review }\end{array}$ & & \\
\hline \multicolumn{2}{|l|}{ 7. Figures } & & \\
\hline \multicolumn{2}{|l|}{ 7.1. Figure 1} & & \\
\hline 7.1.1. Name & Number of publications per year and cumulative sum & & \\
\hline 7.1.2. Elements & $\begin{array}{l}\text { Horizontal - Years from } 2000 \text { to } 2016 \text { with Step } 1 \text { (shows only the } \\
\text { years that there were publications); Vertical on the left - Numbers } \\
\text { from } 0 \text { to } 7 \text { with Step } 1 \text {; Vertical on the right - Numbers from } 0 \text { to } \\
20 \text { with Step 2; Bars - Number of publications per year; Line - } \\
\text { Cumulative number of publications up to the corresponding year }\end{array}$ & & \\
\hline \multicolumn{2}{|l|}{ 7.2. Figure 2} & & \\
\hline 7.2.1. Name & $\begin{array}{l}\text { Information exchange flow of board-level decision-making } \\
\text { process in Japanese companies }\end{array}$ & & \\
\hline 7.2.2. Elements & Detailed description in the Note under the figure above & & \\
\hline \multicolumn{2}{|l|}{ 7.3. Figure 3} & & \\
\hline 7.3.1. Name & Players at the top and types of meetings they interact in & & \\
\hline 7.3.2. Elements & Detailed description in the Note under the figure above & & \\
\hline \multicolumn{2}{|l|}{ 8. Descriptive analysis } & \multirow{6}{*}{$\begin{array}{l}\text { Phase 8: } \\
\text { The report and } \\
\text { recommendations }\end{array}$} & \multirow{6}{*}{$\begin{array}{l}\text { Stage III: } \\
\text { Reporting and } \\
\text { dissemination }\end{array}$} \\
\hline 8.1. Descriptive analysis & $\begin{array}{l}\text { Short explanation of the data as numbers and percentage - } \\
\text { author/year; type of material - article/book; methodology; } \\
\text { country; concepts mentioned; and their derivatives }\end{array}$ & & \\
\hline 8.2. Source of the approach & Pugliese et al. (2009) & & \\
\hline \multicolumn{2}{|c|}{ 9. Thematic results by concepts } & & \\
\hline $\begin{array}{l}\text { 9.1. Thematic results by } \\
\text { concepts }\end{array}$ & $\begin{array}{l}\text { Discussion based on evidence per concepts mentioned: Board of } \\
\text { directors, outside directors, CEO, type of auditors, regulatory act, } \\
\text { type of reform, corporate governance mechanism, process and } \\
\text { their derivatives }\end{array}$ & & \\
\hline 9.2. Source of the approach & Pugliese et al. (2009); Boivie et al. (2016); Khanna et al. (2014) & & \\
\hline
\end{tabular}

